\title{
Potential of Cooperation of Ukraine with Central Asia States and Its Key Concerns
}

\author{
Perspektywy współpracy Ukrainy z państwami Azji Centralnej \\ i potencjalne kwestie problematyczne
}

\section{- Abstrakt •}

Temat artykułu został wybrany ze względu na znaczenie regionu Azji Środkowej dla polityki Ukrainy, szczególnie z uwagi na pragnienie Ukrainy rozwijania wzajemnie korzystnych stosunków z Kazachstanem, Kirgistanem, Tadżykistanem, Turkmenistanem i Uzbekistanem. Ukraina chętnie poszukuje możliwości pogłębienia wzajemnie korzystnych stosunków z tymi państwami. W niniejszym artykule przeanalizowano potencjalnie problematyczne aspekty w interakcjach między Ukrainą a krajami Azji Środkowej w bieżącym okresie ich niepodległości, oraz trendy widoczne w rozwoju współpracy z nimi w świetle znaczącego lokalnego wpływu globalnych mocarstw obecnych w Azji Środkowej, a także poglądy przedstawicieli środowiska naukowego i eksperckiego na kwestie problematyczne, potencjał i perspektywy współpracy Ukrainy z państwami Azji Centralnej, w tym poglądy dotyczące oceny optymalnej metody pozwalającej Ukrainie osiągnąć własne interesy narodowe $\mathrm{w}$ ramach polityki ukraińskiej w regionie Azji Środkowej (biorąc pod uwagę rozwój sytuacji wewnętrznej i zewnętrznej). W artykule skoncentrowano się na potrzebie wy-

\section{- Abstract •}

The research topic has been selected with importance of Central Asian region for Ukraine's politics in mind, specifically Ukraine's desire to develop mutually advantageous relations with Kazakhstan, Kyrgyzstan, Tajikistan, Turkmenistan and Uzbekistan. Ukraine is keen on identifying promising opportunities for deepening its relationship with these states to the benefit of both sides. The present article analyzes the key concerns in interactions between Ukraine and Central Asian countries in the current period of their independence and trends in development of cooperation with them in light of significant influence of major powers present in Central Asia. The paper presents the views of representatives of the scientific and expert community on the concerning issues, as well as on overall potential and prospects of Ukraine's cooperation with Central Asian states. Assessments are made of how the state interests of Ukraine can best be achieved in the country's policy towards Central Asian region, taking into account the evolving situation within and without it. The work focuses on the need for Ukraine to take advantage of geopolitical opportunities emerging in Central 
korzystania przez Ukrainę szans geopolitycznych pojawiających się w Azji Centralnej, szczególnie w kontekście dynamicznego rozwoju procesów politycznych i gospodarczych w regionie. Autor omawia możliwość wdrożenia nowego podejścia dla wspomożenia rozwoju długoterminowej wzajemnie korzystnej współpracy Ukrainy z krajami Azji Środkowej, w tym szeregu opcji współpracy wielostronnej z udziałem wiodących potęg gospodarczych i politycznych świata. Kończąc, autor przedstawia własną wizję rozwoju współpracy Ukrainy z Kazachstanem, Kirgistanem, Tadżykistanem, Turkmenistanem i Uzbekistanem w taki sposób, aby ukraińskie interesy $\mathrm{w}$ regionie zostały osiągnięte $\mathrm{w}$ ramach wielostronnej współpracy między krajami Azji Środkowej, potęgami światowymi i samą Ukrainą.

Słowa kluczowe: Ukraina; kraje Azji Środkowej; wpływ geopolityczny; mocarstwa światowe; współpraca wielostronna
Asia, particularly in the context of dynamic development of political and economic processes in CAR region. The author discusses the possibility of implementing new frameworks to establish long-term mutually beneficial cooperation between Ukraine and Central Asian states, including the multilateral options for development of constructive relations with participation of the global powers. Finally, the author presents own vision of developing Ukraine's cooperation with Kazakhstan, Kyrgyzstan, Tajikistan, Turkmenistan and Uzbekistan in a manner ensuring Ukrainian interests in the region are attained within the framework of multilateral cooperation between CAR countries, world powers and Ukraine itself.

Keywords: Ukraine; Central Asia countries; geopolitical influence; world powers; multilateral cooperation

Ukraine's approach to international cooperation with Central Asia states receives significant attention from representatives of the local expert community. Interactions of Ukraine with Kazakhstan, Kyrgyzstan, Tajikistan, Turkmenistan and Uzbekistan show, according to scholars, that the country does not have a cohesive long-term concept and strategy for developing relations with CAR (Horobets, 2011).

Initially, Ukrainian diplomacy did not pay enough attention to Central Asian region (Lyashenko, 2011). Still, it should be noted that in mid-1990s, Ukraine has made systematic efforts to formulate and implement an active foreign policy towards Central Asian states, focused in particular on ensuring imports of energy and other key categories of technical and industrial goods. A retrospective analysis of the presence of Ukraine in Central Asia demonstrates that over the period of national independence of CAR states, interactions of the Ukrainian business entities with Kazakh, Kyrgyz, Tajik, Turkmen and Uzbek trade partners - particularly in trade of goods - had their share of ups and downs. From the beginning of the 2000s until now, the peak value $\&$ volume of trade in commodities between Ukraine and Central Asian countries was attained in 2008, when it amounted to USD 138 billion. It should be noted that since 2011, there has been a prevailing trend towards a decrease in trade volumes between Ukraine and Central Asian states. In 2017 for example, its total value was at the record low, namely only USD 
1.2 billion; it has picked up somewhat in 2018 when it reached USD 1.5 billion (Foreign Trade of Goods of Ukraine, 2019). One cannot deny the influence of the Russian Federation policies and obstacles raised by that state on the road to implementation of the conceptualized mechanisms of economic cooperation of Ukraine with Kazakhstan, Kyrgyzstan, Tajikistan, Turkmenistan and Uzbekistan.

In general, there are a number of sources of concern when it comes to cooperation of Ukraine with Central Asian countries, that can broadly be categorized as fluctuations in foreign economic activity resulting from several objective and subjective factors. Firstly, these fluctuations are to an extent caused by geopolitical plays made in the region by leading world powers. The axiom is that, either directly or indirectly, the intensity of cooperation between Ukraine and Central Asian countries is determined by the current relationship of Ukraine with the Russian Federation. Usually a significant reduction in cooperation between Ukraine and Central Asian countries, in particular as concerns trade volumes and the overall economic sphere, is due to obstacles artificially created by the Russian Federation to hinder the flow of Ukrainian goods to Kazakhstan, Kyrgyzstan, Tajikistan, Turkmenistan and Uzbekistan. For example, introduction of restrictions on transit of Ukrainian goods through Russia led to a significant uptick in their prices in Central Asian markets, primarily due to an increase in transportation costs on the way to the region.

It should be noted that Ukraine appealed to the WTO to fight this Russian transit ban, which effectively blocked the shortest way of Ukrainian goods to Central Asian markets, but in the WTO decision made in April 2019 the transit restrictions imposed by Russia were not recognized as violation of international law (Ukraine Lost the Transit Dispute With the Russian Federation in the WTO, 2019).

Of course, other actors - manufacturers of similar types of goods from countries competing with Ukraine - attempted to take advantage of the tension between Ukraine and the Russian Federation. Restrictions on transit of goods from Ukraine to Central Asian countries resulted in the decline of exports of traditional Ukrainian products to the markets of Kazakhstan, Kyrgyzstan, Tajikistan, Turkmenistan, Uzbekistan and an opportunity to fill this gap emerged for others. In particular Russia and China were active in trying to take over the market previously served by Ukraine in Central Asia countries. This entire situation is a perfect example of Ukraine's main concerns in its dealings with CAR states.

From a geopolitical perspective, relations between Ukraine and Central Asia are stagnant (Morgatsky, 2017). Ukrainian leadership did not respond to and take advantage of initiatives proposed by some promising partners in CAR countries, what led to drastic weakening of Ukraine's position in the region. The influence of Ukraine in CAR is minimal, the state remains a passive participant in the "Great 
Game" ongoing in Central Asia, satisfied with the mere fact that others are letting it be present there (Lyashenko, 2011).

The former economic, political and humanitarian position of Ukraine is being replaced by the presence of other players who now have significant geopolitical, geo-economic and geo-cultural influence on CAR countries (Ukrainian Prism: Foreign Policy, 2018) - primarily China and Russia.

Analyzing the progress of China's penetration into Central Asian region from the point of view of global geopolitics, experts conclude that with the ever-diminishing level of cooperation of Ukraine with Central Asian states and its retreat from the region - its security and energy interests included - the political and economic vacuum is actively filled by China. The PRC is stepping up activity in its relations with Central Asian states, intensifying its economic cooperation (China Pushes Ukraine from the Region of Central Asia, 2013). According to some researchers, the weakening of Ukraine's position in Central Asia can also be indirectly attributed to the increasing role of energy export to China in foreign policies of various Central Asia states (Opimah, 2010). As concerns the influence of other leading world powers in Central Asia, the impact of the "Russian factor" on Ukraine's position can be summarized thus: "The geopolitical and geo-economic position of the region and the specifics of interstate regional cooperation make Ukraine's access to it critically dependent on the position of the Russian Federation" (Foreign Policy Portal. Section "Central Asia”, 2017).

It should be noted that with the Russian side effectively blocking also the transit of commodities originating in CAR to Ukraine (applicable in particular to transport of energy through the territory of the Russian Federation), there is practically no alternative route to maintain this supply. One of the key problems hindering the transport of oil and natural gas from Central Asia to Ukraine is the absence of a gas and oil pipeline leading from Kazakhstan and Turkmenistan to Azerbaijan, across the Caspian Sea. At the end of the 2010s, experts noted: "The positions of Iran and Russia serve as an obstacle for the construction of pipelines across the Caspian Sea to Azerbaijan" (Kazantsev, 2008). Thus Ukraine found itself in a rather difficult position as concerns the real chances of implementing its plans to diversify its national energy supply with the involvement of Central Asian countries (Opimah, 2010).

Current geopolitical and geo-economic situation in Central Asia forced Ukraine to face the harsh reality of the world powers' struggle for influence in the region. It is still clear that Ukraine remains too slow and hesitant in pursuing the very promising potential of its cooperation with CAR states. The time when Ukraine could at its leisure ponder which projects in the region it would like to 
implement and in what manner is passing, as nowadays real global powers, such as Russia, the United States, and China (and others) are increasingly expressing their interest in CAR (Lyashenko, 2011).

Analysts point out that current interest in Central Asian region on Ukraine's political scene is critically low compared to previous years. In the current platforms of the Ukrainian parliamentary political parties, the subject of developing relations with Central Asia states and actors is virtually absent. CAR countries are not featured as partners, nor is the region itself seen a strategic geography for Ukraine's foreign policy in the official speeches of Ukrainian politicians; in the internal Ukrainian political discourse the region remains pretty much unmentioned. In fact, it can be confidently declared that Ukraine, due to a number of reasons, is missing opportunities for establishing a real political dialogue and economic relations with the countries of post-Soviet Central Asia. Launching a political dialogue with the authoritarian regimes in this region is not considered by domestic political elites a process worthy of personal investment and commitment - the political players in Ukraine recently changed, and the critical decline in cooperation of Ukrainian business circles with the countries of this region further discourages such activity. In the Analytical Report of the Annual Message of the President of Ukraine to the Verkhovna Rada of Ukraine On the Internal and External Situation of Ukraine in 2017, Central Asia region is present only as a transit corridor on the margin of analysis focused on increasing transport volumes from China.

In addition, the level of coordination of activities aimed at cooperation with Central Asian countries between various agencies of the Ukrainian government is quite low. As concerns bilateral relations, the Ukrainian institutions do not demonstrate noticeable coordination, even though the scope of cooperation with CAR states would make it quite easy, it being pretty much limited to official diplomatic missions, and the rare state-funded organizations focused on strengthening cooperation, including trade. In fact, the absence of a coherent economic and political agenda has contributed to Ukraine's withdrawal from the region over medium term (Ukrainian Prism: Foreign Policy, 2018).

The author believes that Ukraine should take an active part in international cooperation in Central Asian region, taking advantage of the still existing factors acting to its benefit in the international arena, before the dynamic political and economic processes in CAR make it impossible.

Any involvement of Ukraine in the changes occurring in Central Asian countries can bring benefits - if not immediately, then in the future (Shergin, 2014). At present, the ongoing shifts and trends in multilateral cooperation in the region seem to make this potential even more tangible. 
In the author's opinion, taking into account the nature of the presence of leading world powers in the region, the overall objective assessment of potential and prospects of Ukraine's relationship with Central Asian states is quite positive, in particular in the context of opportunities arising from various forms of international cooperation in CAR. Among the factors that improve the potential for and long-term benefits resulting of increased trade and economic cooperation of Ukraine with the region is the geopolitical rivalry of global players, including competition in the energy market. In this regard, it is worth quoting the former President of Ukraine V. Yushchenko, who in one of his speeches argued in favor of establishment of energy cooperation between Ukraine and Central Asian states: "We must all understand well that the countries of Central Asia are obviously also striving to be participants in the European energy market. The shortest way to these countries is through Ukraine. This region will play an important role in the global energy market in the next few decades. Ukraine should be politically active in this matter. Our place should be recorded for the interests of Ukraine" (Yushchenko Supports the Establishment of Energy Cooperation Between Ukraine and Central Asia Countries, 2006).

At present, there is an opinion among analysts that it would be expedient to develop a strategic medium- and long-term vision of cooperation with Central Asian states (Foreign Policy Agenda in the Central Asia Region and Strategy for Ukraine, 2018).

Development of mutually beneficial cooperation with Central Asian countries seems, in the author's opinion, one of the important directions for Ukraine's foreign policy of the future, in particular from the perspective of its transnational potential.

When considering the prospects of Ukrainian presence in Central Asian region, it should be noted that Ukraine became a full participant of the TRACECA project, which aims to link pipeline networks, roads, railways, and shipping routes of Central Asian and Caucasian region with the pan-European transport systems (Lyashenko, 2011). The TRACECA programme financed certain infrastructure investments and helped establish common rules for multimodal transport between participating countries (Ruban, 2018). European countries seek to ensure an uninterrupted flow of energy from the Caspian Sea and Central Asia, as well as the security of all transports moving through the territory of TRACECA member states (Parahonsky, 2014). The future of TRACECA is said to depend on the success of the Chinese "One Belt - One Way" strategy, based on the idea of revival of the Great Silk Way (Turaev, 2016). "One Belt - One Way" conceptually seems to be one of the most attractive current initiatives for Ukraine from a geo-economic 
perspective. The project, in particular, could open new alternative routes, reducing the negative consequences of the break-up of economic relations with the Russian Federation and overcoming the ban on transit of Ukrainian goods to Asia (Honcharuk, 2016). Ukraine has a unique chance to join "One Belt - One Way" and contribute to the creation of a new economic order in Europe, Asia and Africa (Povoroznyk, 2015). Ukrainian-Chinese cooperation on developing international transport corridors has significant prospects and great relevance in light of the scale of this project (Diakova, 2018). It should be noted that Ukraine signed an action plan for joining the "One Belt - One Way" initiative (Ukraine - China: Strategic Partnership in a Global Context, 2018). The implementation framework of "One Belt - One Way" strategy does, among others, cover the countries of Central Asia, where construction of industrial production facilities is planned (Povoroznik, 2015). The author believes that, in light of the "One Belt - One Way" project and the real opportunity for future development of multilateral cooperation in Central Asia - in particular with the participation of the People's Republic of China - adding new emphasis on effective cooperation between Ukraine and CAR states in the Ukrainian foreign policy would be a logical move.

A recent significant shift in the international arena offers even greater promise for Ukraine in terms of becoming party to the framework of multilateral cooperation between Central Asian countries and leading world players that offers advantages to all parties. The crucial event bringing about these improved prospects took place on August 12, 2018 in Aktau (Kazakhstan), when the Convention on the Legal Status of the Caspian Sea was signed during the Fifth Caspian Summit, with the participation of presidents of Azerbaijan, Iran, Kazakhstan, Russia and Turkmenistan. The document is aimed at intensification of all types of interactions between the coastal countries (Outcome of the Fifth Caspian Summit: What the Presidents Agreed on, 2018). The signed Convention might bring benefits for the five countries, in particular in the field of extracting, exploring and transporting oil (The Sea of Friendship, the Caspian "Constitution" Opened up the Great Prospects, 2018). Among others, the document outlines the possibility of laying pipelines cutting across the Caspian Sea (Convention on the Legal Status of the Caspian Sea, 2018). In the author's opinion, this is a strategic foundation for furthering the process of building pipeline architecture in the region. Gas and oil pipelines laid under the Caspian Sea would be a practical solution to the long-standing problem of limited access of Central Asian energy carriers to the European market. Such a subsea pipeline, if constructed, would connect the oil and gas systems of Kazakhstan, Turkmenistan and Azerbaijan with the existing network of oil and gas pipelines and related support infrastructure in the west. In the context of 
international cooperation in the energy sector around the Caspian Sea, it should be noted that these new projects of pipelines, which placed the Caspian region countries as the focus of interest of the oil and gas business and global powers, have been developed or brought under discussion with the political support of Western countries (Zhyltsov, 2016). In view of additional analytical materials on geopolitical changes occurring as a result of signing of the Caspian Sea Convention, one could see real opportunity for Turkmenistan to finally realize its cherished dream of building the Trans-Caspian gas pipeline on the sea shelf and pumping gas through Azerbaijan, Turkey and The Black Sea into the EU (Klymenko, 2018).

Detailed analysis of the political and economic situation, giving due consideration to pipeline construction plans in the Caspian region from the perspective of future opportunities to ensure it is able to position itself in the most advantageous manner is extremely important for Ukraine at the moment. In the new circumstances, Ukraine cannot afford to lose this unique chance created by the recent geopolitical and geo-economic changes.

The strategy of European integration and development of cooperation with Central Asian countries do not contradict Ukraine's national interests and other foreign policy priorities (Shergin, 2015). On the contrary, the subsea pipeline through the Caspian Sea in fact addresses both Ukraine's European integration aspirations and its developing cooperation with Central Asian countries. Ukraine can become one of the key links in the transportation corridor bringing Central Asian energy into Europe, what undoubtedly would open new, attractive possibilities of large-scale multilateral cooperation and further improve the standing and significance of the Ukrainian transit route.

In the author's opinion, the chances of successfully deepening and strengthening the relations between Ukraine and Central Asian countries with significant energy resources, such as Kazakhstan, Turkmenistan, Uzbekistan, will depend on political and economic stability in the Caspian region. Success of the Trans-Caspian pipeline construction projects will be decisive for the overall volume of benefits generated for various states. If infrastructure development in the Caspian region is accomplished without major problems, Ukraine would obtain additional opportunities to realize its economic interests as a key transit state in Eurasia - ex. through participating in the development of oil and gas fields in the Caspian Sea basin, hydrocarbon transportation, etc. Ukraine needs to pursue the multiple possible options for its cooperation with Central Asian countries and leading world powers, remaining aware of and carefully navigating the political and economic competition, geopolitical differences and contradictions in the region. 
Taking into account the common interests of Ukraine and countries of Central Asia, as well as the geopolitical situation in Eurasia, the potential benefits to properly defining the strategic goals of the Ukrainian foreign policy in Central Asia and subsequently implementing the policy are significant. In the eyes of the author, CAR states to a certain extent achieve their strategic interests by cooperating with key world players in a multilateral framework, retaining a clear view of political and economic realities and showing good understanding of the current economic aspects in the international arena. Ukraine in turn should focus on the prospects for implementing bilateral and multilateral cooperation with Central Asian countries and global players, particularly in the framework of large-scale projects in the transport and energy sectors. There is true potential in improving and expanding Ukraine relations with Kazakhstan, Kyrgyzstan, Tajikistan, Turkmenistan and Uzbekistan, and a real possibility of successfully pursuing Ukraine's national interests in Central Asia and increasing the efficiency of its foreign policy there through use of new frameworks of international cooperation in the region, transforming to some extent the traditional forms of cooperation with Central Asian countries.

When setting the goals for Ukraine in development of its relations with Central Asian countries, it is important to consider what are the key interests of the global powers - Russia, the USA, China - in the region and what tools they use to achieve their goals. This would help Kyiv not only avoid tension in relations with major world players due to possible conflicts of interests, but also provide an opportunity to decide in which domains its would be prudent and possible to coordinate its own activities with the corresponding actions of Russia, the USA, China to ensure Ukraine's interests are best serves. This applies in particular to those issues where the goals of Ukraine and abovementioned states may coincide or overlap (Murashkina, 2015).

In the author's opinion, it is necessary to find a proper place for Ukraine in the formation and implementation of international cooperation initiatives - in multilateral format - with participation of Central Asian countries and key world powers. With increased activity of the USA and China in Central Asian region and taking into consideration the hindering factors originating in Ukraine's relationship with Russia, Ukraine should increase its collaboration with other actors in the implementation of Ukraine's policies in the Central Asian market. There exist certain opportunities for such cooperation in a multilateral framework, with participation of the USA and China, solidifying the foundation of good mutual relations with these global powers. Today this potential remains untapped as concerns Central Asian direction of the Ukrainian foreign policy. Overall, Ukraine 
meets the criteria for being able to be a real partner for the leading world players and successfully participate in multilateral cooperation efforts in Central Asia. This assessment is primarily based on the country's many years of experience in interaction with Central Asia in various domains, its industrial and technological capabilities and availability of highly qualified specialists with exportable skills in Ukraine.

Cooperation with CAR region could potentially bring benefits in both geopolitical and geo-economic planes for Ukraine. In addition, with the huge potential for international multilateral interaction in Central Asia, it is important for Ukraine to build a systemic strategy of cooperation with Kazakhstan, Kyrgyzstan, Tajikistan, Turkmenistan, Uzbekistan and leading world powers that would maximize such benefits. The first step is to assess the real size of opportunity for obtaining political and economic dividends from participation - on a collaborative basis - in future large-scale projects, particularly those currently in the initial stages of their development.

\section{References:}

China Pushes Ukraine out of the Region of Central Asia (2013). Retrieved from: http:// geostrategy.ua/node/409.

Convention on the Legal Status of the Caspian Sea (2018). Retrieved from: http://kremlin. $\mathrm{ru} / \mathrm{supplement} / 5328$.

Djakova, Y.O. (2018). Ukrainian-Chinese Foreign Economic Relations: Socio-Geographical Aspect, author's abstract. Kiev: Cand. Geographer. Sciences.

Foreign Trade of Ukraine Goods. (2019). Retrieved from: http://www.ukrstat.gov.ua/.

Honcharuk, A.Z., Hobova, Y.V., Kiktenko, V.A., Koval, O.A, Koshovyi, S.A. (2016). Foreign Policy Audit: Ukraine - China. Kyiv: Institute of World Politics.

Horobets, I., Martynov, A. (2011). Central Asian Geopolitical Point. External Affairs, 9, 44-49.

Kazantsev A.A. (2008). Big Game "with Unknown Rules": World Politics and Central Asia. Moscow: MGIMO.

Klymenko, O.Y. (2018). Geopolitical Changes in the Context of the Signing of the Caspian Convention. Gilea, 139, 161-164.

Lyashenko, T.M. (2011). Transformation of Political Systems in Central Asia: National and Regional Aspects. Kyiv: Institute of Political and Ethnonational Studies named after Kuras National Academy of Sciences of Ukraine.

Morgatsky, V. (2017). Ukraine and the States of Central Asia in New Geopolitical Realities: Geo-Economic and Geostrategic Aspects. Bulletin of the Taras Shevchenko National University of Kyiv. Geography, 3(68)/4(69), 180-187.

Murashkina, M.Z. (2015). Interaction and Rivalry of Russia, the USA and China in Central Asia, author's abstract. Mykolayiv: Cand. Flight. Sciences. 
Opimah, R.E. (2010). Strategy of Energy Cooperation of Ukraine with the Countries of Central Asia. Strategic Panorama, 1, 68-80.

Parakhonsky, B.O., Yavorskaya, H.M. (2014). Actual Challenges and Threats to Regional Security: Conclusions for Ukraine. Kiev: NISS.

Portal of Foreign Policy. The Section "Central Asia" (2017). Retrieved from: http://fpp. com.ua/zagalna_info/tsentralnaa-aziya/.

Povoroznyk, V., Perebyinis, V. (2015). The Project "One Belt-One Way": Opportunities for Ukraine. Kyiv: International Center for Policy Studies.

Ruban, S. (2018). Ukrainian-Kazakh Cooperation on the Route of the Great Silk Road. Trends and Prospects for the Development of Science and Education in a Globalization, 198.

Shergin, S.O. (2014). East Asian Regionalism in the Context of Ukraine's Interests: Goals, Priorities, Opportunities and Scenarios of Development. Strategy of Development of Ukraine, 3, 185-200.

Shergin, S.O. (2015). Ukraine-Turkmenistan: Cooperation in the Context of Foreign Policy Priorities. Globalization Challenges and Multilateral Diplomacy, 15-17.

Shved, V.O. (2008). Asian Direction of Foreign Policy of Ukraine: Problems and Prospects. Analytical Estimates. Kiev: NISS.

The Foreign Policy Agenda in the Region of Central Asia and Strategy for Ukraine (2018). Retrieved from: http://da.mfa.gov.ua/wp-content/uploads/2018/09/Zovnishnopolitychnyj-poryadok-dennyj-u-regioni-TSentralnoyi-Aziyi-ta-strategiyi-dlya-Ukrayiny-.pdf.

The Results of the Fifth Caspian Summit: What the Presidents Agreed on (2018). Retrieved from: https://www.inform.kz/en/itogi-pyatogo-kaspiyskogo-sammita-o-chem-dogovorilis-prezidenty_a3352797.

The Sea of Friendship. The Caspian "Constitution" has Opened Great Prospects (2018). Retrieved from: https://mir24.tv/news/16317700/more-druzhby-kaspiiskaya-konstituciya-otkryla-bolshie-perspektivy.

Turaeva, M.O. (2016). Transport and Infrastructure Projects in Eurasia. World of Change, 1, 127-137.

Ukraine - China: Strategic Partnership in a Global Context (2018). Retrieved from: http:// fes.kiev.ua/n/cms/25/?tx_news_pi1\%5Bnews\%5D=410\&tx_news_pi1\%5Bcontroller\%5D=News\&tx_news_pi1\%5Baction $\% 5 \mathrm{D}=$ detail\&cHash=7836f516abab73cecf90541ee9a23c6.

Ukraine Lost its Transit Dispute with Russia in the WTO. (2019). Retrieved from: https:// www.eurointegration.com.ua/news/2019/04/5/7094817/.

Ukrainian Prism: Foreign Policy (2018). Kyiv: NGO "Foreign Policy Council” Ukrainian Prism, Fund them. F. Ebert.

Yushchenko Is in Favor of Establishing Energy Cooperation between Ukraine and the Countries of Central Asia (2006). Retrieved from: http://agrinews.com.ua/show/101006. html.

Zhyltsov, S.S. (2016.05.19). Geopolitical Space of the Caspian Sea the Early XXI Century: Pipeline Architectonics. Proceedings of abstracts of the V International Scientific and Practical Conference In Kiev: "Restructuring Global Space: Historical Imperatives and Challenges", 124-125. 